УДК 338.43:330.34

DOI: $10.15673 /$ fie.v13i3.2134

\author{
Ніколюк О.В. \\ доктор економічних наук, профресор \\ кафедра менеджменту та логістики \\ Одеська національна академія харчових технологій \\ вул. Канатна 112, м. Одеса, Україна, 65039 \\ Email: alenavn11@gmail.com \\ ORCID ID: 0000-0002-1665-0361
}

\title{
СИСТЕМА ЗАБЕЗПЕЧЕННЯ ЕКОЛОГІЧНОЇ БЕЗПЕКИ ПРОМИСЛОВИХ ПІДПРИЄМСТВ В УМОВАХ СТАЛОГО РОЗВИТКУ ЕКОНОМІКИ
}

\begin{abstract}
У статті визначені наукові положення щодо формування структури системи забезпечення екологічної безпеки промислових підприємств в умовах сталого розвитку економіки за рахунок її декомпозиції на підсистеми, яким притаманні відповідні властивості, принципи, завдання та інструменти функціонування. У результаті дослідження встановлено, що екологічна безпека промислових підприємств в умовах сталого розвитку економіки і його суб'єкти формують складну систему, стан якої багато в чому визначає рівень забезпеченості екологічною безпекою продукції промислового виробництва. Виокремлення складових системи забезпечення екологічної безпеки промислових підприємств в умовах сталого розвитку економіки дозволило сформувати власне бачення її природи як процесу, що орієнтується на використання різноманітних методів та основних способів національного господарювання, що одночасно запобігають виникненню негативних екологічно безпечних явищ у промисловому виробництві через втілення новітніх екологічно безпечних, ресурсо- та енергоощадних техніки і технологій, інноваційних розробок у поєднанні з розвитком еколого-економічної освіти, суспільного мислення й об'єктивної поведінки.

Ключові слова: сталий розвиток економіки; промислові підприємства, екологічність, розвиток, система управління.
\end{abstract}

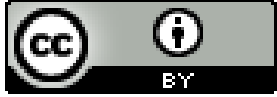

This work is licensed under a Creative Commons Attribution 4.0 International License $\mathrm{http}: / /$ creativecommons.org/licenses/by/4.0/
Постановка проблеми та її зв'язок з важливими науковими та практичними завданнями. Основу політики держави представляють стратегічні орієнтири, що регламентуються певними державними структурами. Зважаючи на основні вимоги сучасності щодо розвитку промислових підприємств та національної економіки загалом, доцільною є розробка стратегії щодо їх екологічної безпеки. Враховуючи погляди науковців сучасності, під стратегією забезпечення екологічної безпеки промислових підприємств в умовах сталого розвитку економіки слід розуміти сукупність найбільш значущих рішень, спрямованих на забезпечення відповідного рівня безпеки у контексті реалізації державних цільових програм. Тобто, така стратегія $є$ довгостроковим прогнозом комплексного розв'язання проблеми збалансованого, з урахуванням еколого-економічних аспектів, забезпечення екологічної безпеки промислових підприємств в умовах сталого розвитку економіки та поліпшення загального стану екологічної системи промислових підприємств. У рамках цього документа відпрацьовуються основні шляхи структурної трансформації промислової політики та розміщення продуктивних сил, що враховують імперативи збалансованого сталого розвитку та забезпечення екологічної безпеки промислових підприємств в умовах сталого розвитку економіки.
На сучасному етапі розвитку суспільства, взаємодії людини із природою забезпечення екологічної безпеки промислових підприємств виступає не ізольованим явищем, а розглядається як імперативна вимога економічної стабільності та $є$ невід'ємною складовою сталого розвитку економіки. Це у свою чергу зумовлює необхідність вивчення механізмів забезпечення екологічної безпеки промислових підприємств в умовах сталого розвитку економіки з метою оптимального, послідовного переходу на якісно нові засади, що є одним із важливих і актуальних наукових завдань сучасності.

За роки незалежності України стан справ із захистом навколишнього середовища, забезпеченням необхідного рівня екологічної безпеки промислових підприємств в умовах сталого розвитку економіки оцінюється як такий, що потребує поліпшення. На рівні держави виникають значні матеріальні й фінансові збитки, як результат нейтралізації надзвичайних ситуацій техногенного характеру. Викиди забруднюючих речовин в атмосферу від стаціонарних джерел постійно зростають. Для запобігання та вирішення вже існуючих екологічних проблем держава повинна застосовувати дієві заходи щодо забезпечення екологічної безпеки промислових підприємств в умовах сталого розвитку економіки. 
Аналіз останніх публікацій по проблемі. В дослідженнях вітчизняних вчених, присвячених проблемам забезпечення екологічної безпеки промислових підприємств в умовах сталого розвитку економіки зазвичай аналізується стан речей, який сформувався у досліджуваній сфері та визначаються пропозиції щодо удосконалення.

Аспекти щодо забезпечення екологічної безпеки промислових підприємств в умовах сталого розвитку економіки розроблялися у працях: В. Борщевського, О. Манойленка, А. Никифорова, В. Русана, П. Саблука, М.Скорика, А. Черепа та ін..

Незважаючи на широкий спектр напрямів дослідження особливостей забезпечення екологічної безпеки промислових підприємств в умовах сталого розвитку економіки, у працях дослідників практично не представлено питання розробки надійної системи забезпечення екологічної безпеки промислових підприємств в умовах сталого розвитку економіки.

Формулювання цілей дослідження. Мета статті полягає в обгрунтуванні складових системи забезпечення екологічної безпеки промислових підприємств в умовах сталого розвитку економіки та конкретизації напрямів і єдиних підходів до управління екологічною безпекою промислових підприємств на засадах сталості економіки.

Виклад основних результатів та їх обгрунтування. Дослідивши різні підходи до розкриття змісту забезпечення екологічної безпеки промислових підприємств в умовах сталого розвитку економіки можна стверджувати, що екологічна безпека промислових підприємств, перш за все, має спрямовуватись на реалізацію таких методів і засобів господарювання, які не призводять до розвитку негативних екологічно небезпечних явищ у відповідній системі або запобігають їх виникненню. У цьому має полягати основна мета забезпечення екологічної безпеки промислових підприємств в умовах сталого розвитку економіки. Якщо процеси деградації навколишнього середовища уже присутні у сучасному вимірі, тоді необхідно розробляти комплекси заходів, які включатимуть екологічно орієнтовані структурні, технологічні, адміністративні рішення задля їх нейтралізації й сприятимуть відтворенню природного капіталу загалом. Суттєво підвищити ефективність забезпечення екологічної безпеки промислових підприємств в умовах сталого розвитку економіки можна за рахунок впровадження новітніх екологічно безпечних, ресурсо- й енергоощадних технологій, нових розробок, із одночасним розвитком економіки і виховання та суспільного мислення загалом.

У цьому зв'язку основне завдання забезпечення екологічної безпеки промислових підприємств в умовах сталого розвитку економіки полягає у підтриманні цілісності промислової системи забезпечення екологічної безпеки промислових підприємств в умовах сталого розвитку економіки, що стає можливим при визнанні взаємозв'язку та змістовності його складових - екологічної, соціальної та економічної (Рис. 1).

Встановлено, що погіршення якості та екологічного стану навколишнього середовища в основному $\epsilon$ ключовою причиною забезпечення зростання рівня захворюваності людей, виникають різні природні катаклізми тощо. За даних обставин не доцільно пропонувати заходи щодо підвищення рівня економічного зростання та благополуччя суспільства. Як результат функціонування системи забезпечення екологічної безпеки промислових підприємств в умовах сталого розвитку економіки усім складовим притаманний соціально-економічний ефекти.

Соціальний ефект полягає у зростанні благополуччя суспільства, зниженні захворюваності серед населення; актуалізації питання розвитку соціальної інфраструктури; зростанні зайнятості шляхом формування нових робочих місць в промисловому виробництві, що дотримуються умов екологічної безпеки. Можливий економічний ефект передбачає скорочення витрат шляхом імплементації енерго- й ресурсозберігаючих технологій й заощадженні на екологоекономічних штрафах і платежах; активізація та вихід на нові ринки еколого-економічної продукції та технологій; отримання прибутків від реалізації екологоекономічних інновацій та екологічно безпечних товарів; формування екологічного іміджу підприємств [1$3]$.

Соціальний ефект доцільно представити через покращення стану довкілля у результаті реалізації екологічно безпечних технологічних й управлінських рішень; збереження й відтворення природних ресурсів; зменшення відповідного рівня антропогенного навантаження на природу.

Встановлено, що екологічна безпека промислових підприємств і його суб'єкти формують складну екологічну систему, стан якої багато в чому визначає рівень забезпечення екологічної безпеки промислових підприємств в умовах сталого розвитку економіки. Управління забезпечення екологічної безпеки промислових підприємств в умовах сталого розвитку економіки представляє собою цілеспрямований вплив соціально-економічної підсистеми на екологічну 3 метою переходу системи в якісно новий стан [4-5].

Система забезпечення екологічної безпеки промислових підприємств в умовах сталого розвитку економіки представляє собою комплексну, впорядковану сукупність підсистем, взаємопов'язаних механізмів, методів і засобів, заходів, що направлені на довгострокове забезпечення стійкості та екологічності промислових підприємств та захищеності інтересів суспільства. Запропонована система має достатньо складну структуру, складовими якої є підсистеми: цільові (структурна, прогнозування і моделювання, оцінки та контролю, прийняття рішень), функціональні, загальні, забезпечення екологічної безпеки промислових підприємств в умовах сталого розвитку економіки. Усі складові системи поєднані між собою системоформуючими зв'язками, під якими слід розуміти способи взаємодії елементів, які забезпечують формування і функціонування системи у часі та просторі. Завдяки таким зв'язкам, формалізованим у межах комплексної системи забезпечення екологічної безпеки промислових підприємств в умовах сталого розвитку економіки, сформована ії раціональна основа - стійка упорядкованість іiї складових і зв'язків, яка включає ієрархічні рівні (міжнародний, державний, регіональний й місцевий). 


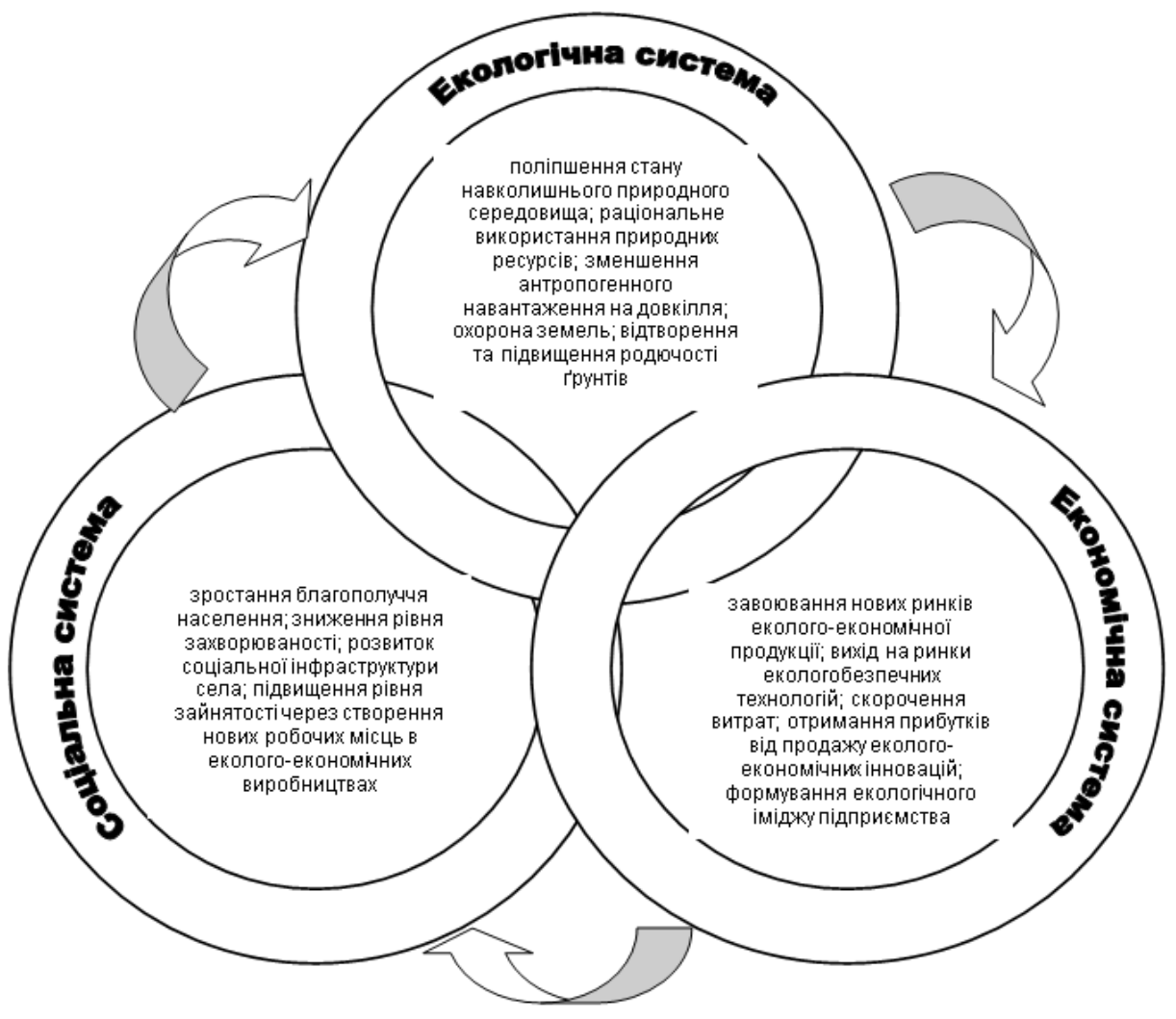

Рис. 1. Комплементарний взаємозв'язок забезпечення екологічної безпеки промислових підприємств в умовах сталого розвитку економіки з соціальною, економічною

і екологічною системами

* побудовано автором

Важливе місце при цьому відводиться саме екологічній безпеці технологічних та управлінських рішень. До пріоритетних завдань забезпечення екологічної безпеки промислових підприємств в умовах сталого розвитку економіки доцільно віднести зміцнення соціально-економічної складової промислових підприємств; мінімізація техногенного навантаження на навколишнє середовище; раціональність використання наявних природних ресурсів; відтворення та підвищення родючості грунтів; імплементація енергоощадних й безвідходних технологій промислового виробництва; підвищення обсягів виробництва саме екологічно безпечної органічної продукції. 3 метою дотримання встановлених цілей й реалізації поставлених завдань варто розробити ефективний інструментарій [6].

Протягом останнього часу активного розвитку набув еколого-економічний аудит та екологоекономічний консалтинг, надання інформаційної й практичної допомоги інвесторам, бізнесу, державі, громадськості для прийняття дієвих управлінських рішень, процесу реалізації еколого-економічних програм і оптимізації провадження природоохоронної діяльності. 3 метою отримання достовірної інформації щодо впливу виробничих процесів на сучасний стан навколишнього природного середовища та виявлення змін, що у ньому відбуваються під впливом зовнішніх і внутрішніх факторів виникає нагальна потреба в належній організації екологічного моніторингу, що проводиться на всіх управлінських рівнях, а саме: світовому, державному, регіональному та локальному.

Основні цілі забезпечення екологічної безпеки промислових підприємств в умовах сталого розвитку економіки вбачаємо в забезпеченні окремих його складових, які об'єднуються в єдину систему. Виокремлення складових системи забезпечення екологічної безпеки промислових підприємств в умовах сталого розвитку економіки дозволило сформувати власне бачення іiі природи як процесу, що орієнтується на використання дієвих методів та ключових способів господарювання, запобігаючи цим самим розвитку негативних екологічно безпечних явищ у промисловому виробництві через втілення новітніх екологічно безпечних, ресурсо- та енергоощадних техніки і технологій, інноваційних розробок у поєднанні з розвитком еколого-економічної освіти, суспільного мислення й об'єктивної поведінки.

Стратегічні цілі в напрямку забезпечення екологічної безпеки промислових підприємств в умовах сталого розвитку економіки відповідають сутності теорії сталого розвитку і віддзеркалюють три його складові: соціальну, економічну та природничу. Виконання кожної із стратегічних задач сприяє досягненню кожної із трьох визначених стратегічних цілей. Постановка оперативних цілей і задач зумовлюється фактичним станом забезпечення екологічної безпеки промислових підприємств в умовах сталого розвитку економіки, станом навколишнього природного середовища, рівнем еколого-економічної свідо- 
мості населення та попитом на екологічно чисту продукцію і сировину, станом системи регулювання, використанням наявних і можливістю залучення додаткових матеріально-технічних ресурсів [7-8].

Теоретично-концептуальні засади забезпечення екологічної безпеки промислових підприємств в умовах сталого розвитку економіки передбачають обов'язкове виділення таких його характеристик, як предмет, суб'єкт та об'єкт управління. Предметом управління забезпечення екологічної безпеки промислових підприємств в умовах сталого розвитку економіки виступає сукупність відносин між забезпеченням екологічної безпеки промислових підприємств в умовах сталого розвитку економіки та суб'єктами управління в сферах якості продукції, екологічного спрямування виробництва, раціональності природокористування i ресурсоспоживання та відтворення природно-ресурсного потенціалу [9-10].

Особливістю державних органів $є$ те, що їх дії мають носити запобіжний, контролюючий, регулюючий характер. Така висока відповідальність обумовлена тим, що держава виступає гарантом прав людини. Регулювання на рівні органів місцевого самоврядування та громадське регулювання частіше носять ініціативний регулюючий характер, громада частіше реагує постфактум і також має ініціативний характер регулювання.

Висновки та перспективи подальших досліджень.Ефективність забезпечення екологічної безпеки промислових підприємств в умовах сталого розвитку економіки є важливим завданням держави та гарантією вирішення соціальних протиріч, забезпечення якості життя. Вивчення наукових праць 3 досліджуваної тематики дозволило сформувати теорети- чне підгрунтя для авторського підходу до розуміння системи забезпечення екологічної безпеки промислових підприємств в умовах сталого розвитку економіки, в основу якої має бути покладено принцип комплексності та системності у напрямку визначення методів, заходів, інструментів та важелів впливу на соціально-економічні відносини, що спрямовані на забезпечення фундаментальних засад забезпечення екологічної безпеки промислових підприємств в умовах сталого розвитку економіки через збереження й відтворення природних ресурсів, залучених у господарський обіг, попередження або недопущення негативного впливу господарської діяльності на екосистеми, створення сприятливих умов для виробництва екологічно безпечної продукції й сировини.

Обгрунтовано комплекс рекомендацій з формування багаторівневої системи забезпечення екологічної безпеки промислових підприємств в умовах сталого розвитку економіки, як комплексної, впорядкованої сукупності підсистем, взаємопов'язаних механізмів, методів і засобів, заходів, що направлені на довгострокове забезпечення стійкості та екологічності економіки та захищеності інтересів суспільства. Запропонована система має достатньо складну структуру, складовими якої є підсистеми: цільові (структурна, прогнозування і моделювання, оцінки та контролю, прийняття рішень), функціональні, загальні, забезпечення екологічної безпеки промислових підприємств в умовах сталого розвитку економіки. Усі складові системи поєднані між собою системоформуючими зв'язками, під якими слід розуміти способи взаємодії елементів, які забезпечують формування і функціонування системи у часі та просторі.

\section{Література}

1. Стратегія розвитку сільського господарства економіки на період до 2020 року. Схвалена Розпорядженням Кабінету Міністрів України від 17 жовтня 2013 p. № 806-p. URL: http://zakon4.rada.gov.ua/laws/show/806-2013-p. (дата звернення: 29.07.2021 p.)

2. Бігдан О. В. Напрями розвитку екологоорієнтованого агровиробництва в міжнародній практиці // Агросвіт. 2013. № 4. С. 29-31.

3. Никифоров А. С. Інноваційна діяльність: теорія і практика державного управління : монографія. К.: KHEУ, 2010. 420c.

4. Череп А. В. Управління інноваційними процесами на підприємстві: сучасні підходи та перспективи //Формування ринкових відносин в Україні: збірник наукових праць. 2014. № 4. С. 43-46.

5. Положення про Міністерство аграрної політики та продовольства України: Затв. Постановою КМУ від 25.11.2015 № 1119. URL: http:// zakon.rada.gov.ua. (дата звернення: 29.07.2021р.)

6. Концепція Державної цільової програми розвитку сільського господарства економіки на період до 2022 року: проект. URL: https://zakon.rada.gov.ua/laws/show/1437-2015-\%D1\%80\#Tехt (дата звернення: 29.07.2021 p.)

7. Nikoliuk O., Gryshova I, Shestakovska T. The organic production in the context of improving the ecological safety of production of the food industry // Food Science and Technology. 2017. 11, 103-111.

8. Ніколюк О.В. Теоретико-методологічні засади інституційного регулювання соціально-економічної безпеки аграрного виробництва: монографія. Одеса: Друкарський дім, Друк Південь, 2018. 298 с.

9. Інституціональна модель інноваційної економіки: колективна монографія / за ред. В. І. Ляшенка, О. В. Прокопенка, В. А. Омельяненка. НАН України, Ін-т економіки пром-сті. Київ, 2019. 327 с.

10. Потенціал розвитку і перспективи відродження сільських територій в умовах сучасних реформ: науковоаналітична доповідь /за ред.. В. Борщевського. Львів, 2017. 43 с.

Стаття надійшла 12.08.2021

Стаття прийнята до друку 26.08.2021 Доступно в мережі Internet 24.10.21 


\author{
Nikoliuk 0. \\ Doctor of Economics, Professor \\ Department of Management and Logistics \\ Odessa National Academy of Food Technologies \\ Kanatna str., 112 Odesa, Ukraine, 65039 \\ E-mail: alenavn11@gmail.com \\ ORCID ID: 0000-0002-1665-0361
}

\title{
SYSTEM OF ENSURING ENVIRONMENTAL SAFETY OF INDUSTRIAL ENTERPRISES IN THE CONDITIONS OF SUSTAINABLE ECONOMIC DEVELOPMENT
}

The article identifies scientific provisions for the formation of the structure of the system of environmental safety of industrial enterprises in terms of sustainable economic development due to its decomposition into subsystems, which have the appropriate properties, principles, objectives and tools. This makes it possible to specify the directions and develop common approaches to the management of environmental safety of industrial enterprises in the context of sustainable economic development in the long run. The main task of environmental safety of industrial enterprises in terms of sustainable economic development is to maintain the integrity of the industrial ecological and economic system and ensure balanced sustainable economic development, which becomes possible by recognizing the relationship and content of its three components - environmental, social and economic. The ecological and economic effect can also be characterized through the improvement of the environment as a result of the introduction of environmentally friendly technological and management solutions; rational use of natural resources for their preservation and reproduction, including soil fertility; reduction of anthropogenic load on the environment. It has been found that the environmental safety of industrial enterprises in terms of sustainable economic development and its subjects form a complex system, the state of which largely determines the level of environmental safety of industrial products. Management of sustainable economic development is a purposeful impact of the socio-economic subsystem on the environment in order to transition the system to a qualitatively new state. Isolation of components of the system of environmental safety of industrial enterprises in terms of sustainable economic development has formed its own vision of its nature as a process aimed at using a set of methods and techniques that prevent the development of negative environmentally safe phenomena in industrial production through the implementation of new environmentally friendly and energy-saving equipment and technologies, innovative developments in combination with the development of environmental and economic education, social thinking and objective behavior.

Key words: sustainable economic development; industrial enterprises, environmental friendliness, development, management system.

\section{References}

1. Stratehiia rozvytku silskoho hospodarstva ekonomiky na period do 2020 roku. Skhvalena Rozporiadzhenniam Kabinetu Ministriv Ukrainy vid 17 zhovtnia 2013 r. № 806-r. Retrieved July 29, 2021, from http://zakon4.rada.gov.ua/laws/show/806-2013-r.

2. Bihdan, O. V. (2013). Napriamy rozvytku ekolohooriientovanoho ahrovyrobnytstva $v$ mizhnarodnii praktytsi. Ahrosvit, (4), 29-31.

3. Nykyforov, A. Ye. (2010). Innovatsiina diialnist: teoriia i praktyka derzhavnoho upravlinnia. KNEU.

4. Cherep, A. V. (2014). Upravlinnia innovatsinymy protsesamy na pidpryiemstvi: suchasni pidkhody ta perspektyvy. Formuvannia rynkovykh vidnosyn v Ukraini, (4), 43-46.

5. Polozhennia pro Ministerstvo ahrarnoi polityky ta prodovolstva Ukrainy: Zatv. Postanovoiu KMU vid 25.11.2015 № 1119. Retrieved July 29, 2021, from http://zakon.rada.gov.ua

6. Kontseptsiia Derzhavnoi tsilovoi prohramy rozvytku silskoho hospodarstva ekonomiky na period do 2022 roku: proekt. Retrieved July 29, 2021, from https://zakon.rada.gov.ua/laws/show/1437-2015-\%D1\%80\#Text

7. Nikoliuk, O., Gryshova, I, \& Shestakovska, T. (2017). The organic production in the context of improving the ecological safety of production of the food industry. Food Science and Technology, (11), 103-111.

8. Nikoliuk, O. V. (2018). Teoretyko-metodolohichni zasady instytutsiinoho rehuliuvannia sotsialnoekonomichnoi bezpeky ahrarnoho vyrobnytstva. Drukarskyi dim, Druk Pivden.

9. Liashenka, V. I., Prokopenka, O. V., \& Omelianenka, V.A. (Eds.). (2019). Instytutsionalna model innovatsiinoi ekonomiky. NAN Ukrainy, In-t ekonomiky prom-sti. 
10. Borshchevskoho, V. (Ed.). (2017). (rep.). Potentsial rozvytku i perspektyvy vidrodzhennia silskykh terytorii v umovakh suchasnykh reform.

Received 12 August 2021

Approved 26 August 2021

Available in Internet 24.10.21

Цитування згідно ДСТУ 8302:2015

Ніколюк О.В. Система забезпечення екологічної безпеки промислових підприємств в умовах сталого розвитку економіки // Економіка харчової промисловості. 2021. Т.13, вип. 3. С.70-75. doi: 10.15673/fie.v13i3.2134

Cite as APA style citation

Nikoliuk, O. (2021). System of ensuring environmental safety of industrial enterprises in the conditions of sustainable economic development. Food Industry Economics, 13(3), 70-75. doi: 10.15673/fie.v13i3.2134 